\title{
III. Abbreviations
}
A. Anguttaranikäya
C- Cone Edition (Tibetan Buddhist Canon)
ch. chüan
Cv. Cullavagga
D. Dighanikaya
D- Sde-dge Edition (Tibetan Buddhist Canon)

Divy. Divyāvadāna

Edg. F. Edgerton, Buddhist Hybrid Sanskrit Dictionary

H. Han'gul taejanggyong kanhaeng mo

HDJK. Han'gul-dae-jang-kyøng

Itiv. Itivuttaka

J. Jataka

KDJK. Koryz-dae-jang-kyöng

L- Lhasa Edition (Tibetan Buddhist Canon)

M. Majjhimanikaya

Mano. Manorathapūrant 
Mv. Mahāvagga

Mvy. Mahāvyutpatti

N- Snar-than Edition (Tibetan Buddhist Canon)

Nj. $\quad$ B. Nanjio, A Catalogue of the Chinese Translations of the Buddhist Tripitaka.

O. A Comparative Analytical Catalogue of the Kanjur Division of the Tibetan Tripitaka (Ōtani University).

Ono. Ono Gemmyo, ed. Bussho kaisetsu daijiten.

P. Peking Edition (Tibetan Buddhist Canon)

S. Samyuttanikāya

Śiks. S Sikṣasamuccaya

Snp. Suttanipātā

T. Taishō shinsh̄ daizōkyō

Thera G. Theragāth $\bar{a}$

Therī G. Theriga $\bar{t} t h \bar{a}$

To. H. Ui, ed. A Complete Catalogue of the Tibetan Buddhist Canon (Tohoku University). 